\title{
Interacting Signal Pathways Control Defense Gene Expression in Arabidopsis in Response to Cell Wall-Degrading Enzymes from Erwinia carotovora
}

\author{
Cecilia Norman-Setterblad, ${ }^{1}$ Sabina Vidal, ${ }^{1}$ and E. Tapio Palva ${ }^{2,3}$ \\ ${ }^{1}$ Department of Plant Biology, Swedish University of Agricultural Sciences, Box 7080, SE-750 07 Uppsala, \\ Sweden; ${ }^{2}$ Department of Biosciences, Division of Genetics, and ${ }^{3}$ Institute of Biotechnology, University \\ of Helsinki, Box 56, Helsinki, FIN-00014 Finland \\ Accepted 28 December 1999.
}

\begin{abstract}
We have characterized the role of salicylic acid (SA)independent defense signaling in Arabidopsis thaliana in response to the plant pathogen Erwinia carotovora subsp. carotovora. Use of pathway-specific target genes as well as signal mutants allowed us to elucidate the role and interactions of ethylene, jasmonic acid (JA), and SA signal pathways in this response. Gene expression studies suggest a central role for both ethylene and JA pathways in the regulation of defense gene expression triggered by the pathogen or by plant cell wall-degrading enzymes (CF) secreted by the pathogen. Our results suggest that ethylene and $\mathrm{JA}$ act in concert in this regulation. In addition, CF triggers another, strictly JA-mediated response inhibited by ethylene and SA. SA does not appear to have a major role in activating defense gene expression in response to CF. However, SA may have a dual role in controlling CFinduced gene expression, by enhancing the expression of genes synergistically induced by ethylene and JA and repressing genes induced by JA alone.
\end{abstract}

Additional keywords: elicitors, soft rot.

Plants have the ability to defend themselves against pathogen attack by activating series of both local and systemic defense responses. These responses may be triggered by a race/ cultivar specific recognition event, as in the genefor-gene type of interaction, where resistance depends on matching of a dominant avirulence ( $a v r)$ gene from the pathogen and a corresponding resistance gene $(R)$ from the host (Flor 1971; Martin et al. 1993; Staskawicz et al. 1995). In addition to such specific resistance, plant defense responses can be activated by a range of unspecific biotic or abiotic elicitors (Nürnberger et al. 1994, 1995; Benhamou 1996). In both cases, the responses appear to involve transcriptional activation of defense genes and de novo synthesis of proteins, including enzymes involved in the biosynthesis of phytoalexins, defensins, and pathogenesis-related (PR) proteins (Bol et al. 1990; Kombrink and Somssich

Corresponding author: E. Tapio Palva; Telephone: +356 9191 59600; Fax: +358 9191 59076; E-mail: tapio.palva@ helsinki.fi

Cecilia Norman-Setterblad and Sabina Vidal contributed equally to this study.
1995; Penninckx et al. 1996). In many plant species, local infection by incompatible pathogens leads to the induction of a broad-spectrum disease resistance in uninfected parts of the plant, termed systemic acquired resistance (SAR) (Ryals et al. 1996). In tobacco and A. thaliana, the onset of SAR correlates with the local and systemic expression of a set of genes called SAR genes (Ward et al. 1991; Uknes et al. 1992). Several of these genes encode members of the family of PR proteins, in particular the secreted acidic isoforms, that can be used as molecular markers to evaluate the development of this response (Ward et al. 1991). Salicylic acid (SA) has been shown to play a key role in the signal transduction pathway leading to SAR and the expression of SAR genes (Malamy et al. 1990; Métraux et al. 1990; Ward et al. 1991). Direct evidence supporting this involvement comes from analysis of transgenic tobacco and A. thaliana plants expressing the nahG gene of Pseudomonas putida. The $n a h G$ gene product, salicylate hydroxylase, converts SA into its inactive form, cathecol. The inability of these plants to accumulate SA leads to the incapability of developing SAR and SAR gene expression in response to pathogen invasion or SA treatment (Gaffney et al. 1993; Delaney et al. 1994; Lawton et al. 1995).

Recent studies by a number of laboratories have indicated the importance of SA- and SAR-independent defense responses. These include responses to fungi (Penninckx et al. 1996, 1998), Erwinia carotovora subsp. carotovora (Vidal et al. 1997, 1998), and growth-promoting rhizobacteria (Pieterse et al. 1996, 1998). A different form of induced systemic resistance (ISR) is triggered by nonpathogenic, root-colonizing rhizobacteria (Pseudomonas fluorescens) (Pieterse et al. 1996, 1998). In contrast to other systemic resistance responses, ISR does not result in PR gene activation.

Plant hormones like ethylene and jasmonates have been implicated in SA-independent defense responses. Ethylene levels have been shown to increase upon wounding or infection by pathogens, as well as from treatment with elicitors of defense responses (Boller 1991; Enyedi et al. 1992). Ethylene treatment induces several genes encoding PR proteins but, in contrast to SA, mainly the basic vacuolar isoforms (Boller 1988; Bol et al. 1990). Genetic evidence from ethylene-insensitive mutants of A. thaliana has shown that ethylene is not required for SAR (Lawton et al. 1995). 
Jasmonic acid (JA) and its methyl ester, methyl jasmonate (MeJA), accumulate both locally and systemically during the wound response of plants or upon elicitor treatment (Creelman et al. 1992; Gundlach et al. 1992). In addition, JA and MeJA induce the expression of genes involved in plant defense responses, including genes for phytoalexin biosynthesis (Gundlach et al. 1992), proteinase inhibitors (Farmer et al. 1992), thionins (Epple et al. 1995), and defensins (Penninckx et al. 1996). Recently, evidence has emerged regarding the involvement of ethylene and jasmonates in the defense response toward non-host-specific pathogens. Transgenic tobacco plants insensitive to ethylene and $A$. thaliana mutants unable to accumulate JA showed increased susceptibility to infection by Pythium spp., which normally are nonpathogenic fungi (Knoester et al. 1998; Vijayan et al. 1998). Both jasmonate and ethylene have been shown to play an important role in the ISR signaling pathway, although genes known to be activated by these phytohormones are not induced during ISR (Pieterse et al. 1998).

The Gram-negative bacterium Erwinia carotovora subsp. carotovora and other soft-rot erwinias constitute one of the most important groups of plant-pathogenic bacteria. This pathogen is the causal agent of potato soft rot and is destructive to a wide variety of plants under the right environmental conditions (Pérombelon and Kelman 1980; Kotoujansky 1987). Breeders have not yet identified any genetic traits of resistance that may be introduced into cultivars and the development of resistance to this pathogen seems to depend on generally induced defense mechanisms (Palva et al. 1993 , 1994). The pathogenicity of E. carotovora subsp. carotovora is thought to be correlated with its ability to produce and secrete a large arsenal of plant cell wall-degrading enzymes, including pectinases and cellulases. These enzymes have been proposed to have a dual role: in addition to being the main virulence determinants of the pathogen (Collmer and Keen 1986; Kotoujansky 1987; Pirhonen et al. 1991), they also trigger plant defense (Davis and Ausubel 1989; Palva et al. 1993; Vidal et al. 1998). We have previously demonstrated that treatment of tobacco plants with acellular preparations of cell wall-degrading enzymes from E. carotovora subsp. carotovora induces both local and systemic expression of several genes encoding PR proteins (Palva et al. 1993; Vidal et al. 1997, 1998). Moreover, we have shown that these enzymes induce both local and systemic resistance responses to this pathogen in tobacco (Palva et al. 1993; Vidal et al. 1998). Although we demonstrated that exogenous $\mathrm{SA}$ induces resistance to $E$. carotovora subsp. carotovora (Palva et al. 1994), SA did not appear to be involved in the activation of defense mechanisms upon E. carotovora subsp. carotovora infection in tobacco. This suggested a role for other signal transduction pathways involved in plant resistance to $E$. carotovora subsp. carotovora.

In this study, we have further elucidated the role of both SA-dependent and SA-independent signal transduction cascades in the activation of defense gene expression upon treatment of $A$. thaliana plants with plant cell wall-degrading enzymes from E. carotovora subsp. carotovora. Our results show that ethylene and JA have a central role in regulating plant defense gene expression as well as resistance against $E$. carotovora subsp. carotovora in this interaction.

\section{RESULTS}

\section{A. thaliana as a model system for studying the interaction between $E$. carotovora subsp. carotovora and plants.}

Our earlier studies have shown that inoculation of tobacco plants with the phytopathogen E. carotovora subsp. carotovora or treatment of the plants with plant cell wall-degrading enzymes from this pathogen induces the expression of a number of basic PR proteins as well as increased systemic resistance to the pathogen in an SA-independent manner (Palva et al. 1993; Vidal et al. 1997, 1998). To facilitate further characterization of the signaling events that mediate the plant responses to E. carotovora subsp. carotovora, we employed $A$. thaliana as a model. Inoculation of $A$. thaliana leaves with $E$. carotovora subsp. carotovora results in the development of soft-rot symptoms that can be mimicked by treatment of plants with culture filtrates $(\mathrm{CF})$ from E. carotovora subsp. carotovora containing the secreted plant cell wall-degrading enzymes from this pathogen (Fig. 1A).

To determine whether CF treatment could also enhance resistance against E. carotovora subsp. carotovora in A. thaliana, seedlings were pretreated with CF. Local application of $\mathrm{CF}$ to $A$. thaliana leaves was followed by inoculation of systemic leaves with E. carotovora subsp. carotovora suspensions. The effect of CF pretreatment on bacterial growth was clear (Fig. 1B). The number of viable bacteria was found to be 5 to 10 times higher in mock-treated plants than in plants pretreated with CF. This indicates, as previously shown in tobacco (Vidal et al. 1998), that CF can trigger enhanced systemic resistance (ESR) to further bacterial infection in $A$. thaliana. Taken together, these results indicate that $A$. thaliana provides a suitable model system to study plant defense responses to E. carotovora subsp. carotovora.

\section{E. carotovora subsp. carotovora and CF induce local and systemic expression of defense genes in A. thaliana.}

Pathway-specific defense genes have been described for ethylene-, JA-, and SA-dependent pathways, providing markers to study pathogen-induced signaling events. To establish the role of ethylene, JA and SA in the A. thaliana defense response to E. carotovora subsp. carotovora, five genes were employed as markers for the different pathways. These included the following: two ethylene-responsive genes, the gene for hevein-like protein (HEL) (Potter et al. 1993), and a basic chitinase (CHIB) (Samac et al. 1990); two JA-responsive genes, the gene for vegetative storage protein acid phosphatase (AtVSP) (Berger et al. 1995) and a defensin (PDF1.2) (Penninckx et al. 1996); and one SA-responsive gene, $P R-1$ (Uknes et al. 1992). Expression of these genes was characterized by Northern (RNA) hybridization in local and systemic leaves following inoculation with bacteria or treatment with $\mathrm{CF}$. Figure 2 illustrates the expression pattern of these genes in treated (local) and untreated (systemic) leaves 8 and $24 \mathrm{~h}$ after treatment. Expression of HEL, AtVSP, and PDF1.2 was strongly induced by $\mathrm{CF}$ and bacteria in both local and systemic leaves already after $8 \mathrm{~h}$. A somewhat weaker but prominent induction was seen for $C H I B 24 \mathrm{~h}$ after treatment. In contrast, only a very weak induction of the SAR marker $P R-1$ was observed in response to bacterial inoculation or CF treatment. $P R-1$ was strongly induced in plants treated with SA whereas no transcript accumulation was evident for the other 
genes tested. No significant increase of gene expression was detected in the mock-treated controls.

Taken together, these results demonstrate that E. carotovora subsp. carotovora induces both local and systemic expression of genes mainly responsive to ethylene or JA but not the SAR gene $P R-1$. Furthermore, similar induction of target genes was achieved both by treatment with $\mathrm{CF}$ and by inoculation with E. carotovora subsp. carotovora suspensions. Consequently, this enabled us to use CF as a tool to study responses of $A$. thaliana to this pathogen.

\section{CF induction of defense related genes is dependent on ethylene and JA signaling pathways.}

To clarify the role of ethylene and JA signal transduction pathways in the $A$. thaliana defense response to $E$. carotovora subsp. carotovora, we characterized the expression pattern of

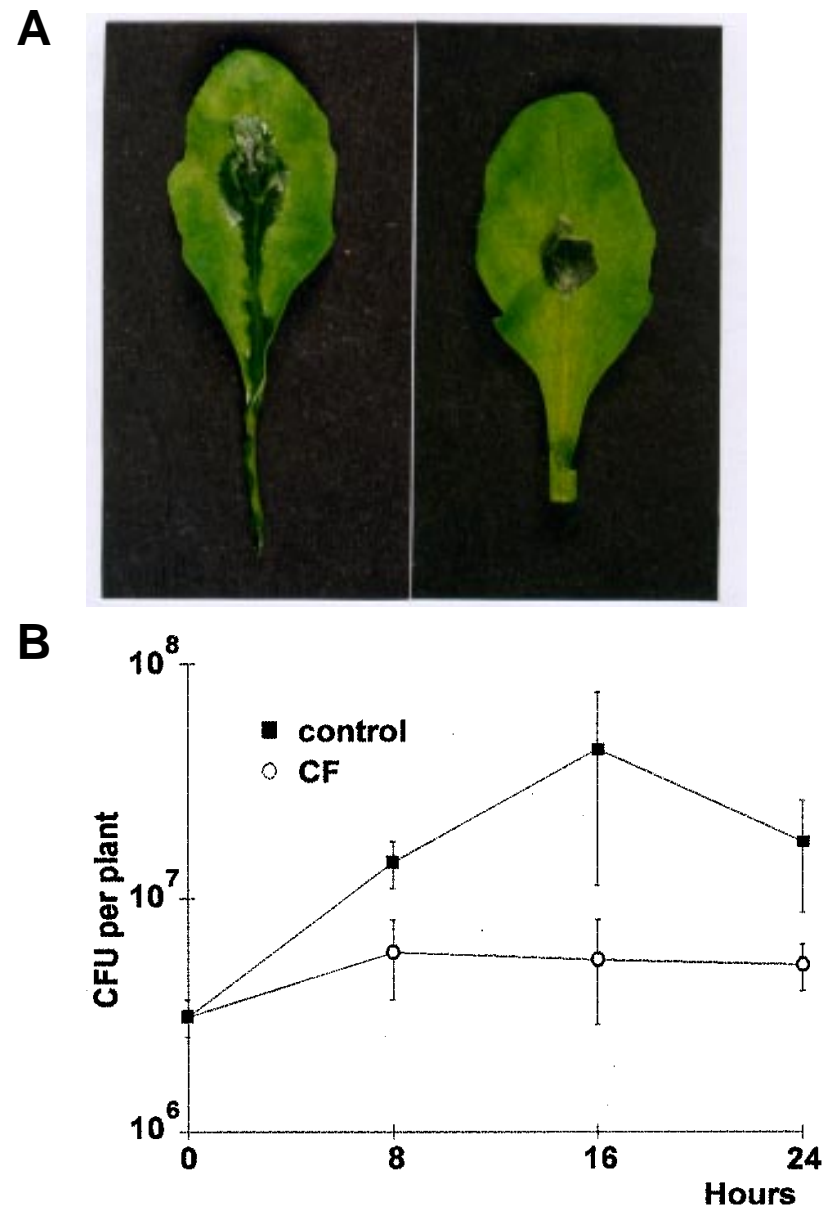

Fig. 1. Infection of Arabidopsi thaliana plants with Erwinia carotovora subsp. carotovora. A, Development of soft-rot symptoms $24 \mathrm{~h}$ after inoculation of $A$. thaliana leaves with 2 to $3 \times 10^{6} \mathrm{CFU}$ of $E$. carotovora subsp. carotovora o.n.c. (overnight culture; left panel) or in a leaf treated with $10 \mu \mathrm{l}$ of culture filtrate (CF; right panel). B, Effect on $E$. carotovora subsp. carotovora growth in planta after CF treatment of $A$. thaliana plants. A. thaliana plants were pretreated with $15 \mu \mathrm{l}$ of $\mathrm{CF}$ in one leaf or with $20 \mathrm{mM} \mathrm{MgCl} 24 \mathrm{~h}$ before inoculation of a second leaf with 2 to $3 \times 10^{6} \mathrm{CFU}$ of E. carotovora subsp. carotovora o.n.c. At indicated time points after inoculation, number of viable bacteria was determined from CF-treated $(\mathrm{CF})$ or $20 \mathrm{mM} \mathrm{MgCl}_{2}$-treated (control) plants. Six independent experiments were carried out. SD indicated by error bars.
HEL, CHIB, PDF1.2 and AtVSP by Northern hybridization in several $A$. thaliana mutants after spray treatment with $\mathrm{CF}$. Transcript accumulation for these genes was analyzed in wildtype plants (Col-0), the ethylene-insensitive mutants etrl and ein2 (Bleecker et al. 1988; Guzmán and Ecker 1990), the JAinsensitive mutant coil (Feys et al. 1994), and the LOX2 cosuppressed transgenic plant line S-12T (Bell et al. 1995). S$12 \mathrm{~T}$ plants have reduced levels of lipoxygenase 2 and are affected in the production of JA in response to wounding (Bell et al. 1995). Accumulation of HEL, CHIB, PDF1.2, and AtVSP transcripts was strongly induced in wild-type plants 8 and $24 \mathrm{~h}$ after $\mathrm{CF}$ treatment, compared with control plants (Fig. 3). CF induction of $H E L$ and $C H I B$ genes was markedly reduced in the ethylene-insensitive mutants (etr1, ein2) and in the jasmonate insensitive mutant coil, and somewhat reduced in the S-12T transgenic plants. CF-induced expression of PDF1.2 was reduced to background levels in the coil and S$12 \mathrm{~T}$ plants and reduced in the ethylene mutants. In contrast, although accumulation of AtVSP transcript was blocked in the coil plants and reduced in the S-12T plants, AtVSP exhibited a stronger $\mathrm{CF}$ induction in the ethylene-insensitive mutants than in the wild type.

Taken together, these results indicate that both ethylene and JA signal transduction pathways are involved in CF induction of $H E L, C H I B$, and PDF1.2. In contrast, induction of AtVSP in response to $\mathrm{CF}$ appears to be strictly dependent on the JA pathway.

\section{$\mathrm{SA}$ is not required for $\mathrm{CF}$-induced gene expression but may potentiate CF induction of ethylene- and $\mathrm{JA}$-responsive defense genes.}

To elucidate whether SA had any role in the regulation of the CF-inducible genes, we characterized the induction pattern of the marker genes in plants affected in SA accumulation and in SA signaling. CF-induced expression of HEL, CHIB, $P D F 1.2$, AtVSP, and $P R-1$ was characterized in wild-type plants (Col-0), transgenic NahG plants, and nprl-mutant

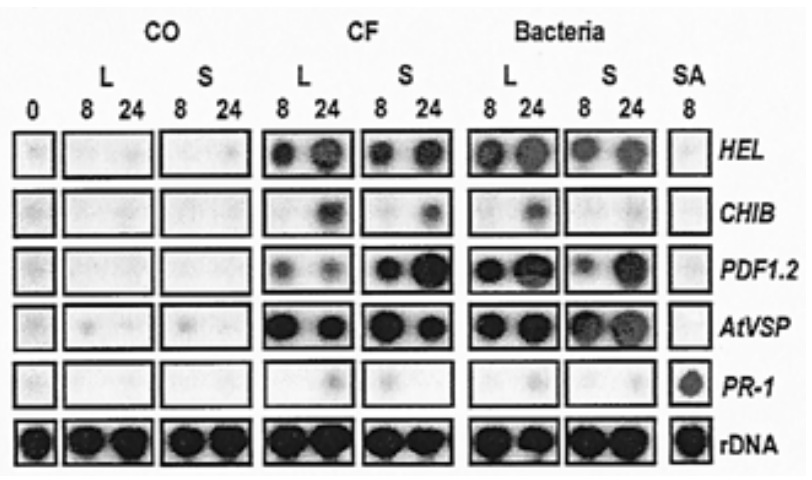

Fig. 2. Erwinia carotovora subsp. carotovora and culture filtrates (CF) induce local and systemic expression of defense genes in Arabidopsis thaliana. In vitro-grown $A$. thaliana plants (Col-0) were treated with $\mathrm{CF}$ from E. carotovora subsp. carotovora $(\mathrm{CF}), 2 \times 10^{6} \mathrm{CFU}$ of E. carotovora subsp. carotovora suspensions (bacteria), or $20 \mathrm{mM} \mathrm{MgCl} 2(\mathrm{CO})$. Treated (local, L) and untreated (systemic, S) leaf samples were collected 8 and $24 \mathrm{~h}$ after treatment. Salicylic acid (SA) treatments were done by spraying whole plants with $5 \mathrm{mM} \mathrm{SA}$ and samples were collected $8 \mathrm{~h}$ after treatment. Total RNA was extracted and analyzed by Northern (RNA) hybridization with specific probes for $H E L, C H I B$, $P D F 1.2$, AtVSP and PR-1. To ensure equal loading of RNA the same filters were hybridized with a probe against ribosomal RNA (rDNA). 
plants blocked in SA-induced expression of PR genes. The results in Figure 4 show that CF-induced accumulation of $H E L, C H I B$, and PDF 1.2 transcripts was slightly reduced in NahG plants, compared with wild-type plants. In contrast, this reduction was not evident in $n p r l$ mutants, where these transcripts accumulated at levels similar to or higher than those in wild-type plants. These data suggest that full CF induction of $H E L, C H I B$, and PDF1.2 genes requires SA acting in an NPR1-independent manner. CF-induced accumulation of AtVSP transcripts was unaffected in $n p r l$ plants. In contrast, expression of this gene was enhanced in NahG plants, indicating that AtVSP could be negatively regulated by the presence of SA. $P R-1$ was only weakly induced by CF treatment in wild-type plants and this induction was blocked in NahG plants or reduced in $n p r l$ plants.

\section{CF-induced defense genes are synergistically regulated by ethylene and $\mathrm{JA}$.}

Our results (Fig. 3) suggested the involvement of both ethylene and JA signal pathways in CF-induced activation of plant defense genes. Previous studies have indicated that ethylene and JA act in concert to regulate the expression of the tobacco PR-gene osmotin and a defensin (PDF1.2) from A. thaliana (Xu et al. 1994; Penninckx et al. 1998). This prompted us to investigate whether $\mathrm{CF}$ induction of $H E L$, $C H I B$, AtVSP, and PDF 1.2 requires both ethylene and JA. To examine this, the expression of these genes was characterized after treatment of $A$. thaliana wild-type plants with $\mathrm{CF}$, ethylene, MeJA, SA, or different combinations of ethylene, MeJA, and SA (Fig. 5). RNA was extracted from leaf tissue harvested $24 \mathrm{~h}$ after treatment and mRNA accumulation was analyzed by Northern hybridization. CF treatment of plants induced the expression of HEL, CHIB, and PDF1.2 to a much higher extent than treatment with either ethylene or MeJA alone. However, when ethylene and MeJA were applied to plants in combination, the expression of HEL, CHIB, and PDF1.2 genes increased synergistically, reaching levels similar to or higher than those obtained by CF treatment. In contrast, the expression of AtVSP was strongly induced by MeJA alone. reaching much higher levels of induction than after $\mathrm{CF}$ treatment.
When plants were treated with MeJA and ethylene in combination, the level of induction of AtVSP was markedly decreased. These results suggest that the induction of $H E L, C H I B$, and $P D F 1.2$ genes upon $\mathrm{CF}$ treatment could result from a synergistic effect between the ethylene and JA pathways. In contrast, the CF-induced expression of AtVSP appears to be strictly dependent on JA and repressed by the presence of ethylene. Treatment with SA did not induce any of the marker genes.

Treatment with SA in combination with ethylene induced the expression of $H E L, C H I B$, and PDF1.2 to slightly higher levels than achieved by ethylene alone. No induction of AtVSP could be seen after this treatment. Similarly, treatment with $\mathrm{SA}, \mathrm{MeJA}$, and ethylene in combination enhanced the expression of HEL, CHIB, and PDF1.2 whereas expression of AtVSP was reduced to background level. This suggests that SA could potentiate the synergistic effect seen on the induction of HEL, CHIB, and PDF1.2 by MeJA and ethylene.

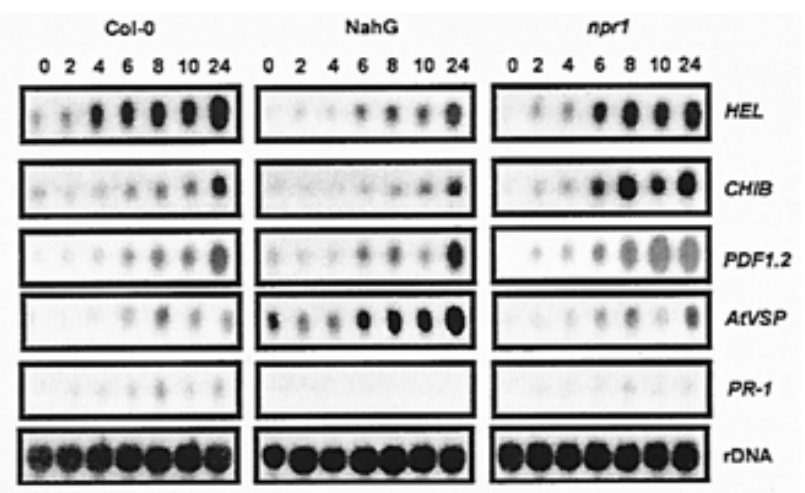

Fig. 4. Salicylic acid (SA) enhances culture fitrate (CF) induction of defense- but not wound-related genes. The transcript accumulation of $H E L, C H I B, P D F 1.2, A t V S P$, and $P R-1$ was characterized after CF treatment of wild-type plants (Col-0), transgenic NahG plants, or $n p r l$ mutants. Plants were spray treated with $\mathrm{CF}$ and leaf samples were collected at the time points indicated. Total RNA was extracted and analyzed by Northern (RNA) hybridization with gene-specific probes. To ensure equal loading of RNA, the same filters were hybridized with a probe against ribosomal RNA (rDNA).

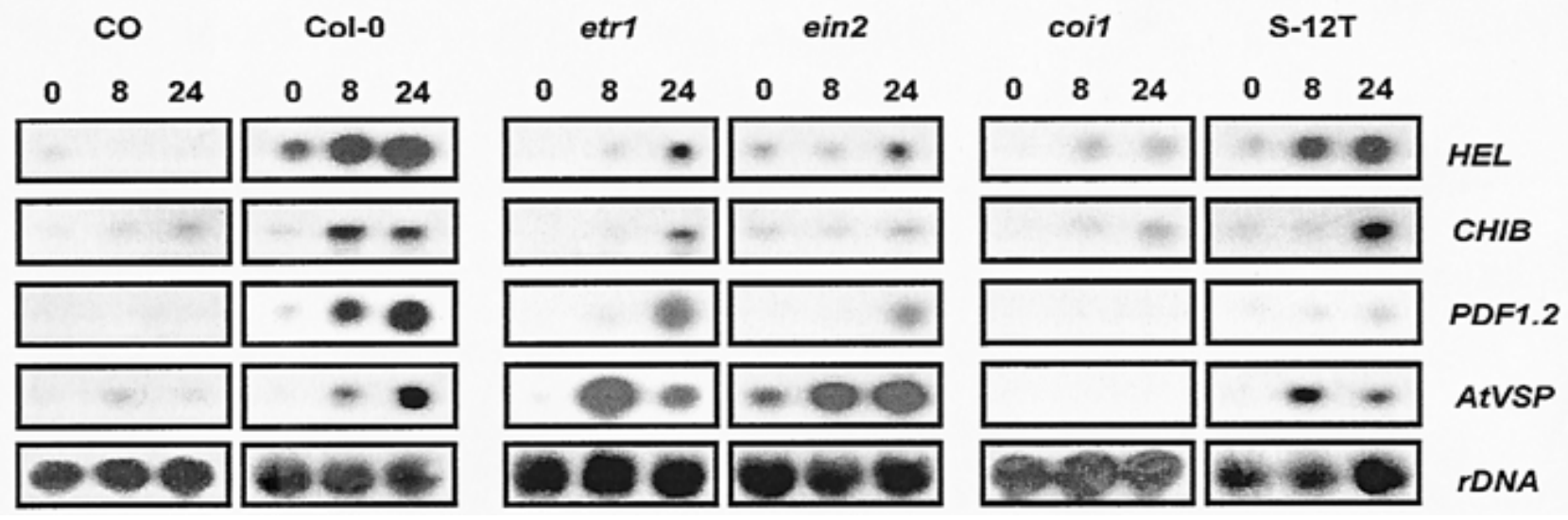

Fig. 3. Erwinia carotovora culture filtrate (CF) induction of defense genes is dependent on ethylene and jasmonic acid (JA) signaling pathways. Transcript accumulation of $H E L, C H I B, P D F 1.2$, and AtVSP after CF spray treatment was characterized in wild-type plants (Col-0), the ethylene-insensitive mutants etr1 and ein2, the JA-insensitive mutant coil, and LOX2 co-suppressed transgenic plants (S-12T). As a control (CO), wild-type plants (Col-0) were treated with $20 \mathrm{mM} \mathrm{MgCl}$. Eight and $24 \mathrm{~h}$ after $\mathrm{CF}$ treatment, leaf samples were collected and total RNA was extracted. Transcript accumulation was analyzed in Northern (RNA) hybridization. To ensure equal loading of RNA the same filters were hybridized with a probe against ribosomal RNA (rDNA). 
Ethylene and JA pathways are involved in the enhancement of local resistance against $\boldsymbol{E}$. carotovora subsp. carotovora.

To establish the requirement for ethylene and JA in resistance to E. carotovora subsp. carotovora, we compared bacterial growth in wild-type (Col-0), ein2 mutant, coil mutant, and NahG transgenic plants. Plants were locally inoculated with 2 to $3 \times 10^{6} \mathrm{CFU}$ and the number of viable bacteria was determined $24 \mathrm{~h}$ after inoculation. The results in Figure 6 show that ein 2 and coil plants were more susceptible to $E$. carotovora subsp. carotovora, as the number of viable bacte-

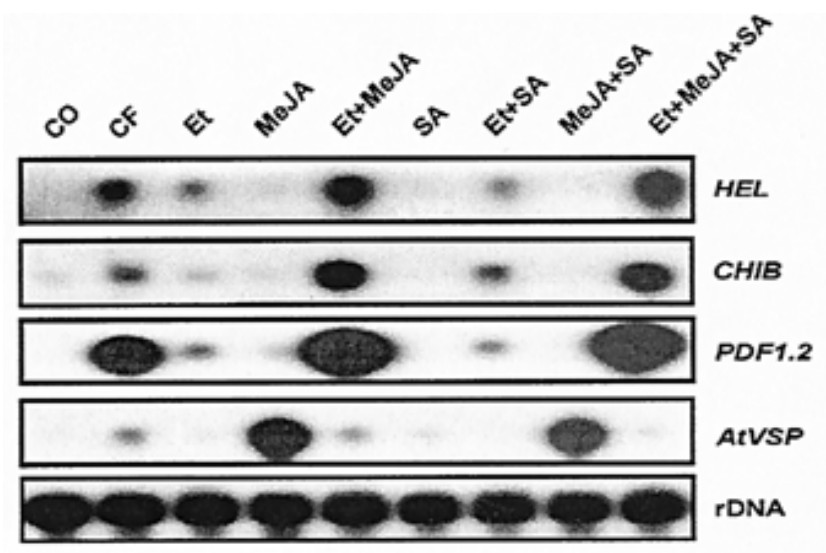

Fig. 5. Culture filtrate (CF)-induced defense genes are synergistically regulated by ethylene and jasmonic acid (JA). Arabidopsis thaliana wild-type plants (Col-0) were treated with CF, $50 \mathrm{ppm}$ of ethylene (Et), $4.6 \mu \mathrm{mol}$ of methyl jasmonate (MeJA), $0.25 \mathrm{mM}$ SA (SA), a combination of $50 \mathrm{ppm}$ ethylene and $4.6 \mu \mathrm{mol}$ of MeJA (Et +MeJA), a combination of $50 \mathrm{ppm}$ ethylene and $0.25 \mathrm{mM}$ SA (Et+SA), a combination of 4.6 $\mu \mathrm{mol}$ of MeJA and $0.25 \mathrm{mM} \mathrm{SA}(\mathrm{MeJA}+\mathrm{SA}$ ), or a combination of 50 ppm ethylene, $4.6 \mu \mathrm{mol}$ of MeJA and $0.25 \mathrm{mM}$ SA (Et+MeJA+SA). Leaf samples were collected $24 \mathrm{~h}$ after treatment and analyzed by Northern (RNA) hybridization with specific probes for $H E L, C H I B, P D F 1.2$, and AtVSP. Below, the amount of the corresponding RNA samples is indicated by hybridizing the same filters with a probe against ribosomal RNA (rDNA).

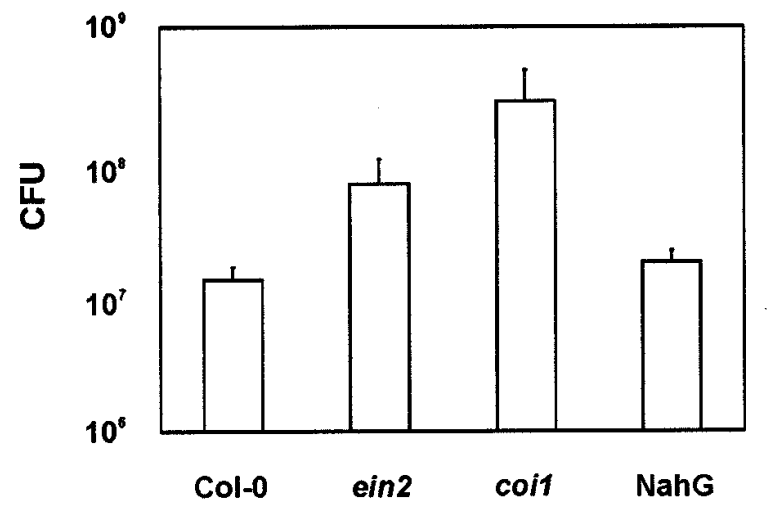

Fig. 6. Ethylene and jasmonic acid (JA) are involved in the enhancement of systemic resistance against Erwinia carotovora subsp. carotovora. Arabidopsis thaliana wild-type plants (Col-0), ethylene-insensitive mutant ein2, JA-insensitive mutant coil, or transgenic NahG plants were inoculated with 2 to $3 \times 10^{6} \mathrm{CFU}$ of E. carotovora subsp. carotovora. Twenty-four hours after treatment, the number of viable bacteria was determined. Each point is equal to eight independent experiments. SD are indicated with error bars. ria reached 7 to 10 times higher levels than in the wild-type plants. In contrast, the lack of SA in the transgenic NahG plants did not result in significantly higher susceptibility to infection by this pathogen. In conclusion, these results suggest that ethylene and JA signaling are involved in resistance to $E$. carotovora subsp. carotovora. Although SA may contribute to potentiate this process, the lack of SA does not appear to influence the development of disease in plants infected with $E$. carotovora subsp. carotovora.

\section{DISCUSSION}

To elucidate the signal processes that activate plant defense in response to E. carotovora subsp. carotovora, we have employed A. thaliana as a model plant due to the availability of mutants and marker genes in pathogen-induced signal transduction pathways. In this study, we show that A. thaliana is susceptible to E. carotovora subsp. carotovora (Fig. 1A). Moreover, we show, in accordance with our previous results with tobacco (Vidal et al. 1998), that treatment of A. thaliana with acellular preparations of cell wall-degrading enzymes prior to bacterial inoculation leads to enhanced systemic re-

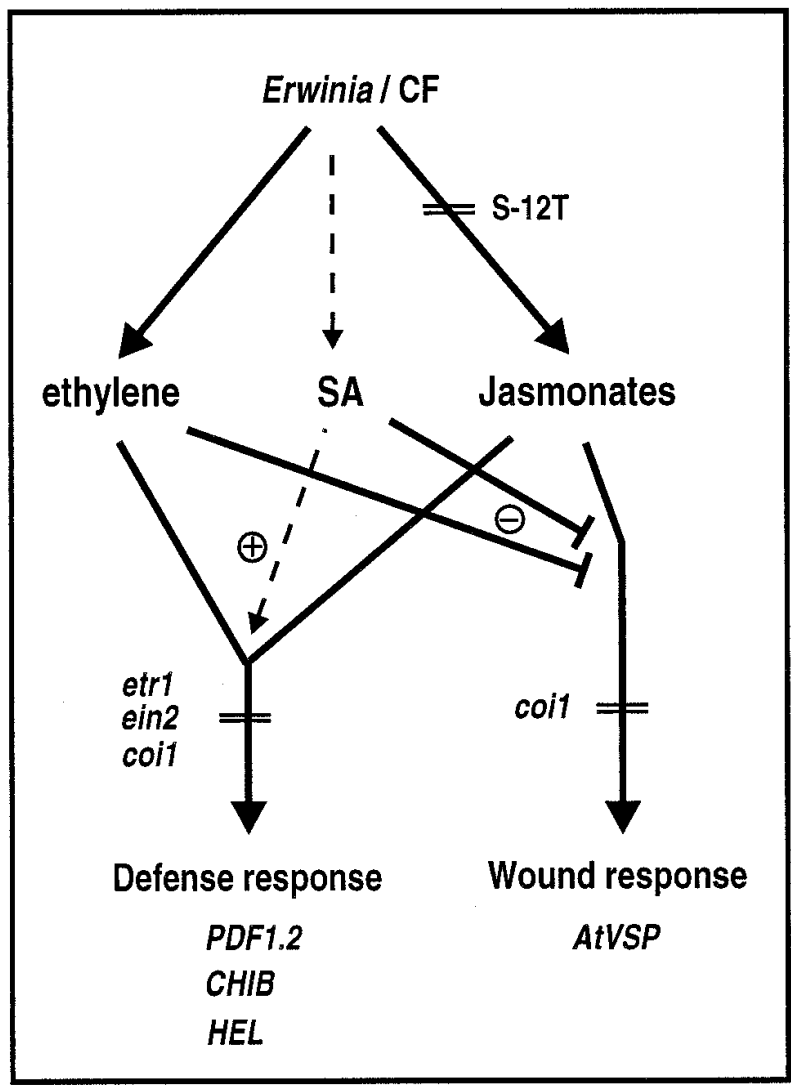

Fig. 7. Interacting signal transduction pathways control expression of Arabidopsis thaliana defense genes in response to cell wall-degrading enzymes (CF) secreted by Erwinia carotovora subsp. carotovora. E. carotovora subsp. carotovora triggers two distinct response pathways in A. thaliana. Synergistic action of ethylene and jasmonates is required for expression of $H E L, C H I B$, and PDF1.2. This induction is enhanced by the presence of salicylic acid (SA). Jasmonates alone mediate CF-induced expression of AtVSP. This pathway is inhibited by SA and ethylene. 
sistance to E. carotovora subsp. carotovora. We therefore conclude that $A$. thaliana provides a suitable model system to study plant defense responses induced by this pathogen.

To elucidate the role of ethylene, JA, and SA signaling pathways in this interaction, we have characterized the expression of marker genes specific to these pathways in response to inoculation of plants with E. carotovora subsp. carotovora or treatment with $\mathrm{CF}$ from the pathogen. The results are summarized in the model presented in Figure 7, highlighting the importance of both ethylene and JA signaling in the plant response to E. carotovora subsp. carotovora. The experimental evidence for this conclusion is as follows. Bacterial inoculation or CF treatment of wild-type plants leads to both local and systemic expression of genes that are mainly responsive to ethylene or JA (Fig. 2) (HEL, CHIB, PDF 1.2, and $A t V S P$ ). In contrast, $P R-1$, an SA-responsive gene, is only weakly induced upon CF treatment. The induction of $H E L$, $C H I B$, and $P D F 1.2$ genes by $C F$ was reduced or blocked in ethylene-insensitive mutants as well as in the coil mutant affected in the JA pathway, indicating that both signaling pathways are required for this response. In contrast, SA signaling did not appear to play a major role in this response since CFinduced expression of these genes was unaffected in nprl mutants and only marginally reduced in NahG plants.

Our results suggest that E. carotovora subsp. carotovora not only induces genes controlled by ethylene and JA but also JA-specific genes such as AtVSP exhibiting a JA-mediated but ethylene-independent induction by CF (Fig. 7). This gene has previously been shown to be strongly induced by MeJA, wounding (Berger et al. 1996), and plant cell wall-derived oligogalacturonide elicitors (OGAs) released by CF (Norman et al. 1999).

Our results suggest a synergistic action of ethylene and JA in CF-induced expression of defense genes (Fig. 7). Addition of ethylene or MeJA alone only results in a very modest induction of defense genes. In contrast, ethylene and MeJA added in combination synergistically induce the expression of $H E L, C H I B$, and PDF1.2 genes, but not AtVSP, to levels achieved by $C F$ treatment. This is in agreement with previous results showing that ethylene and MeJA synergistically induce the expression of osmotin, a tobacco PR-5 gene (Xu et al. 1994) as well as a defensin gene, PDF1.2, in A. thaliana (Penninckx et al. 1998). How MeJA or JA interact with ethylene and co-regulate gene expression is not known. However, it has been shown that ethylene and JA do not act in a sequential manner but rather via parallel and cooperative signaling events in the regulation of PDF1.2 (Penninckx et al. 1998). EIN2 acts downstream of the ethylene receptor in the ethylene signal transduction pathway (Kieber 1997). Interestingly, ectopic expression of EIN2 in ein2 plants was sufficient to restore the ethylene signaling required for the JA induction of PDF1.2 (Alonso et al. 1999).

Our results indicate that the SAR pathway does not play a major role in activating defense genes induced by E. carotovora subsp. carotovora or by $\mathrm{CF}$ treatment (Fig. 7). Only a weak accumulation of $P R-1$ transcript, a very sensitive marker for the SAR pathway, was observed after CF treatment. Nevertheless, our results indicate that SA is involved in the regulation of genes that are strongly induced upon CF treatment (Fig. 7). SA appears to have a dual role in this regulation. First, it is required for the full $\mathrm{CF}$ induction of defense genes
(HEL, CHIB, and PDF1.2) as suggested by reduced expression of these genes in transgenic NahG plants. Second, CF treatment of NahG plants leads to an increased expression of a jasmonate-responsive gene (AtVSP), indicating that SA inhibits $\mathrm{CF}$ induction of this gene by blocking the JA pathway. Similar SA inhibition of the JA pathway was previously demonstrated by Doares et al. (1995) and Peña-Cortés et al. (1993).

The data presented here support the idea that SA, besides inducing SAR and SAR gene expression, may have an indirect role by potentiating the expression of other defense responses that are not directly responsive to SA but become induced upon pathogen attack (Mur et al. 1996; Shirasu et al. 1997). Interestingly, CF treatment of the A. thaliana mutant $n p r 1$ induced $H E L, C H I B$, and PDF 1.2 expression to the same extent as, or even higher levels than, those obtained in wildtype plants. The results show that although the presence of SA may be necessary for full induction of ethylene- and JAresponsive genes, this induction does not require components downstream of SA in the signaling pathway, such as a functional NPR1. This is in contrast to ISR, which develops independently of SA but requires a functional NPR1 (Pieterse et al. 1998; Pieterse and van Loon 1999). Furthermore, ISR is not associated with PR gene expression (Pieterse et al. 1998; Pieterse and van Loon 1999), which distinguishes ISR from the defense response activated by E. carotovora subsp. carotovora.

In summary, our results indicate that E. carotovora subsp. carotovora or $\mathrm{CF}$ triggers two distinct defense pathways in Arabidopsis (Fig. 7). The first is mediated through the synergistic action of ethylene and jasmonates, potentiated by SA, and leads to expression of PDF1.2, CHIB, and HEL. The second pathway is strictly jasmonate mediated, inhibited by ethylene or SA, and controls expression of AtVSP. The latter could be triggered by recognition of OGAs and shares similarities with the wound response of plants.

Ethylene and JA are involved not only in triggering expression of plant defense genes but also in resistance against $E$. carotovora subsp. carotovora infection in A. thaliana. Evidence for this was provided by experiments showing that ethylene- (ein2) and jasmonate- (coil) insensitive mutants were more susceptible to this pathogen than wild-type or transgenic NahG plants. Previous studies with ein 2 mutants have indicated that this mutation generates a lack of development of disease symptom upon infection, suggesting that ethylene is not involved in resistance responses, but instead promotes disease severity (Bent et al. 1992). In contrast to these observations, we show that the degree of E. carotovora subsp. carotovora growth in the ein 2 mutants was consistently enhanced, compared with bacterial growth in wild-type plants. A similar increase in susceptibility has also been observed in ein2 mutants inoculated with the fungal pathogen Alternaria brassicicola (Penninckx et al. 1996).

In conclusion, ethylene and JA pathways appear to have a central role in regulating defense gene induction and resistance triggered by cell wall-degrading enzymes from $E$. carotovora subsp. carotovora (Fig. 7). As shown, induction of defense gene expression appears to be achieved by a combination of signals rather than the activation of single signal pathways. It is possible that when plants fail to accumulate high levels of SA necessary for induction of SAR and SAR gene expression upon pathogen attack, lower levels of SA might have a crucial role in modulating other types of defense 
responses. Depending on the conditions, the activation of this type of defense mechanism by virulent pathogens such as $E$. carotovora subsp. carotovora may be enough to restrict pathogen growth in the infected plant.

\section{MATERIALS AND METHODS}

\section{Plant material and growth conditions.}

Seeds of $A$. thaliana ecotype Columbia (Col-0) were surface sterilized, sown on sterile MS-2 medium (Murashige and Skoog 1962), and replanted in 300-ml jars after germination. Plants were thereafter grown for 2 weeks in a Conviron growth chamber at $22^{\circ} \mathrm{C}$ with a 16 -h light regime (120 to 170 $\mu \mathrm{mol} \mathrm{s}{ }^{-1} \mathrm{~m}^{-2}$ ) before analysis. Treatments of plants were done under a constant light regime with the same conditions. Ethylene-responsive mutants etr1-1 (Bleecker et al. 1988) and ein21 (Guzmán and Ecker 1990) were obtained from the Arabidopsis Biological Resource Center (Columbus, OH; accession numbers CS237 and CS3071). The transgenic A. thaliana line expressing the $n a h G$ gene (Delaney et al. 1994) was provided by John Ryals (Ciba Geigy, Research Triangle Park, NC). The nprl mutant (Cao et al. 1994) was provided by Xinnian Dong (Duke University, Durham, NC). Transgenic LOX2-deficient A. thaliana line S-12T (Bell et al. 1995) was provided by Erin Bell (Texas A\&M University, College Station). The JAinsensitive mutant coil (Feys et al. 1994) was provided by John G. Turner (School of Biological Sciences, University of East Anglia, Norwich, UK).

\section{Bacterial growth and inoculation of plants.}

The Erwinia carotovora subsp. carotovora strain SCC3193, (Pirhonen et al. 1988) was cultured overnight at $28^{\circ} \mathrm{C}$ in $\mathrm{L}$ medium (Miller 1972). To evaluate bacterial growth in planta, plants were inoculated with $10 \mu \mathrm{l}$ of a $10 \times$ dilution of the bacterial overnight culture containing 2 to $3 \times 10^{6} \mathrm{CFU}$. After inoculation, plants were incubated for the indicated time periods under high humidity conditions to facilitate bacterial growth. Bacterial growth in planta was evaluated by homogenizing the inoculated plants in $10 \mathrm{ml}$ of $10 \mathrm{mM} \mathrm{MgSO}_{4}$ and plating serial dilutions onto L agar plates. Each sample contained four plants. The number of viable bacteria was then counted in eight independent experiments.

\section{Chemical applications and extracellular enzyme preparation and treatments.}

CF from E. carotovora subsp. carotovora was prepared as previously described (Vidal et al. 1997). CF treatments were done by spraying plants with $2 \mathrm{ml}$ of CF per jar. For analysis of systemic induction patterns, two leaves per plant were treated by applying $15 \mu \mathrm{l}$ of $\mathrm{CF}$ or bacterial culture, pressing the tip of a pipette to cause a small wound (local). Two opposite leaves were analyzed for systemic defense gene expression. Leaf tissue corresponding to at least 12 plants was pooled and analyzed by Northern hybridization. Control plants were treated with $20 \mathrm{mM} \mathrm{MgCl} 2$ in the same way. SA treatments were done by spraying plants with $2 \mathrm{ml}$ of $5 \mathrm{mM} \mathrm{SA}$ per jar. Controls for this treatment were done by spraying $2 \mathrm{ml}$ of sterile water. SA treatment in combination with other treatments was done by spraying plants with $2 \mathrm{ml}$ of $0.25 \mathrm{mM}$ SA. Ethylene treatments were performed by placing jars in an airtight chamber with $80 \%$ humidity containing air only (control), or $50 \mathrm{ppm}$ of ethylene. Ethylene concentration was measured by a photoionizer (PI 101 trace gas analyzer; HNU Systems, Newton, MA). MeJA treatments were done by placing a cotton stick containing $4.6 \mu \mathrm{mol}$ of MeJA (Bedoukian Research, Danbury, CT) diluted in 96\% ethanol, in a $300-\mathrm{ml}$ jar, or only $96 \%$ ethanol as a control.

\section{PCR amplification of target genes.}

All DNA probes were generated by polymerase chain reaction (PCR) with $A$. thaliana genomic DNA as a template. The DNA fragment corresponding to the HEL gene was generated with primers corresponding to bases 131 to 155 and 571 to 595 of the cDNA sequence (Potter et al. 1993). A fragment of the coding region of the $A$. thaliana basic chitinase $(\mathrm{CHIB})$ (Samac et al. 1990) was obtained with primers corresponding to bases 1625 to 1650 and 2137 to 2163 of the genomic sequence. The $P R-1$ probe was obtained with primers corresponding to 191 to 220 and 466 to 495 of the cDNA sequence (Uknes et al. 1992). The probe for AtVSP (Potter et al. 1993) was generated with primers corresponding to bases 3 to 25 and 214 to 236 of the clone ATTS0751 (Höfte et al. 1992). The probe for PDF1.2 (Penninckx et al. 1996) was generated with primers corresponding to bases 30 to 49 and 262 to 281 of the sequence of the expressed sequence tag T04323. All amplified fragments were cloned into the pCR 2.1 vector (Invitrogen, San Diego, CA).

\section{RNA extractions and Northern hybridization analyses.}

Total RNA from plant leaf tissue, corresponding to 12 plants, was prepared by phenol/chloroform extraction and $\mathrm{LiCl}$ precipitation essentially as described by Verwoerd et al. (1989) with an extra ethanol precipitation step added before the $\mathrm{LiCl}$ precipitation. Ten micrograms of total RNA was denatured in formamide and separated by electrophoresis through formaldehyde agarose gels (Sambrook et al. 1989). Filters were hybridized with $\left[\alpha-{ }^{32} \mathrm{P}\right] \mathrm{dCTP}$-labeled probes generated by multipriming (Amersham, Buckinghamshire, UK) with an EcoRI fragment of the different clones as DNA template. Hybridizations were performed as previously described (Vidal et al. 1997). RNA gels were analyzed with ethidium bromide and blots were probed with a ribosomal probe to ensure equal loading of RNA in each sample.

\section{ACKNOWLEDGMENTS}

We wish to thank John Ryals for the generous gift of seeds of transgenic $A$. thaliana carrying the $n a h G$ gene, Xinnian Dong for the nprl mutant seeds, Erin Bell for the transgenic S-12T A. thaliana seeds, and John G. Turner for the coil mutant seeds. We thank the Arabidopsis Biological Resource Center (Columbus, $\mathrm{OH}$ ) for providing seeds from the ethylene response mutants. We are grateful to Mona Munther for preparing the plant material and to Marcos Montesano for help with ethylene treatments. This work was supported by SIDA, the Swedish Council for Forestry and Agricultural Research (SJFR), the Swedish Natural Sciences Research Council (NFR), and the Foundation in Memory of Oskar and Lili Lamm. The Nilsson-Ehle foundation is gratefully acknowledged. E. T. P. is also supported by the Academy of Finland, Biocentrum Helsinki, and the EU (contract no. ERBIC15-CT96-0908).

\section{LITERATURE CITED}

Alonso, J. M., Hirayama, T., Roman, G., Nourizadeh, S., and Ecker, J. R. 1999. EIN2, a bifunctional transducer of ethylene and stress responses in Arabidopsis. Science 284:2148-2152. 
Bell, E., Creelman, R. A., and Mullet, J. E. 1995. A chloroplast lipoxygenase is required for wound-induced jasmonic acid accumulation in Arabidopsis. Proc. Natl. Acad. Sci. USA 92:8675-8679.

Benhamou, N. 1996. Elicitor-induced plant defence pathways. Trends Plant Sci. 1:233-240.

Bent, A. F., Innes, R. W., Ecker, J. R., and Staskawicz, B. J. 1992. Disease development in ethylene-insensitive Arabidopsis thaliana in fected with virulent and avirulent Pseudomonas and Xanthomonas pathogens. Mol. Plant-Microbe Interact. 5:372-378.

Berger, S., Bell, E., and Mullet, J. E. 1996. Two methyl jasmonateinsensitive mutants show altered expression of AtVsp in response to methyl jasmonate and wounding. Plant Physiol. 111:525-531.

Berger, S., Bell, E., Sadka, A., and Mullet, J. E. 1995. Arabidopsis thaliana Atvsp is homologous to soybean $V s p A$ and $V s p B$, genes encoding vegetative storage protein acid phosphatases, and is regulated similarly by methyl jasmonate, wounding, sugars, light and phosphate. Plant Mol. Biol. 27:933-942.

Bleecker, A. B., Estelle, M. A., Somerville, C., and Kende, H. 1988. Insensitivity to ethylene conferred by a dominant mutation in Arabidopsis thaliana. Science 241:1086-1089.

Bol, J. F., Linthorst, H. J. M., and Cornelissen, B. J. C. 1990. Plant pathogenesis-related proteins induced by virus infection. Annu. Rev. Phytopathol. 28:113-138.

Boller, T. 1988. Ethylene and the regulation of antifungal hydrolases in plants. Pages 145-174 in: Oxford Surveys of Plant Molecular and Cell Biology. B. J. Miflin and H. F. Miflin, eds. Oxford University Press, Oxford.

Boller, T. 1991. Ethylene in pathogenesis and disease resistance. Pages 293-314 in: The Plant Hormone Ethylene. A. K. Mattoo and J. C. Suttle, eds. CRC Press, Boca Raton, FL.

Cao, H., Bowling, S. A., Gordon, S., and Dong, X. 1994. Characterization of an Arabidopsis mutant that is nonresponsive to inducers of systemic acquired resistance. Plant Cell 6:1583-1592.

Collmer, A., and Keen, N. T. 1986. The role of pectic enzymes in plant pathogenesis. Annu. Rev. Phytopathol. 24:383-409.

Creelman, R. A., Tierney, M. L., and Mullet, J. E. 1992. Jasmonic acid/ methyl jasmonate accumulate in wounded soybean hypocotyls and modulate wound gene expression. Proc. Natl. Acad. Sci. USA 89: 4938-4941.

Davis, K. R., and Ausubel, F. M. 1989. Characterization of elicitorinduced defense responses in suspension-cultured cells of Arabidopsis. Mol. Plant-Microbe Interact. 2:363-368.

Delaney, T. P., Uknes, S., Vernooij, B., Friedrich, L., Weyman, K., Negrotto, D., Gaffney, T., Gut-Rella, M., Kessmann, H., Ward, E., and Ryals, J. 1994. A central role of salicylic acid in plant disease resistance. Science 266:1247-1250.

Doares, S. H., Narvàez-Vàsquez, J., Conconi, A., and Ryan, C. A. 1995. Salicylic acid inhibits synthesis of proteinase inhibitors in tomato leaves induced by systemin and jasmonic acid. Plant Physiol. 108: $1741-1746$

Enyedi, A., Yalpani, N., Silverman, P., and Raskin, I. 1992. Signal molecules in systemic plant resistance to pathogens and pests. Cell 70:879886.

Epple, P., Apel, K., and Bohlmann, H. 1995. An Arabidopsis thaliana thionin gene is inducible via a signal transduction pathway different from that for pathogenesis-related proteins. Plant Physiol. 109:813820.

Farmer, E. E., Johnson, R. R., and Ryan, C. A. 1992. Regulation of expression of proteinase inhibitor genes by methyl jasmonate and jasmonic acid. Plant Physiol. 98:995-1002.

Feys, B. J. F., Benedetti, C. E., Penfold, C. N., and Turner, J. G. 1994 Arabidopsis mutants selected for resistance to the phytotoxin coronatine are male sterile, insensitive to methyl jasmonate, and resistant to a bacterial pathogen. Plant Cell 6:751-759.

Flor, H. H. 1971. Current status of the gene-for-gene concept. Annu. Rev. Phytopathol. 9:275-296.

Gaffney, T., Friedrich, L., Vernooij, B., Negrotto, D., Nye, G., Uknes, S., Ward, E., Kessmann, H., and Ryals, J. 1993. Requirement of salicylic acid for the induction of systemic acquired resistance. Science 261: 754-756.

Gundlach, H., Müller, M. J., Kutchan, T. M., and Zenk, M. H. 1992. Jasmonic acid is a signal transducer in elicitor-induced plant cell cultures. Proc. Natl. Acad. Sci. USA 89:2389-2393.

Guzmán, P., and Ecker, J. R. 1990. Exploiting the triple response of
Arabidopsis to identify ethylene-related mutants. Plant Cell 2:513523.

Höfte, H., Desprez, T., Amselem, J., Chiapello, H., Caboche, M., Moisan, A., Jourjon, M.-F., Charpenteau, L., Berthomieu, P., Guerrier, D., Giraudat, J., Quigley, F., Thomas, F., Yu, D.-Y., Mache, R., Raynal, M., Cooke, R., Grellet, F., Delseny, M., and Parmentier, Y. 1992. An inventory of 1152 expressed sequence tags obtained by partial sequencing of cDNAs from Arabidopsis thaliana. Plant J. 4:1051-1061.

Kieber, J. J. 1997. The ethylene response pathway in Arabidopsis. Annu. Rev. Plant Physiol. Plant Mol. Biol. 48:277-296.

Knoester, M., van Loon, L. C., van den Heuvel, J., Hennig, J., Bol, J. F., and Linthorst, J. M. 1998. Ethylene-insensitive tobacco lacks nonhost resistance against soil-borne fungi. Proc. Natl. Acad. Sci. USA 95: 1933-1937.

Kombrink, E., and Somssich, I. E. 1995. Defense responses of plants to pathogens. Adv. Bot. Res. 21:1-34.

Kotoujansky, A. 1987. Molecular genetics of pathogenesis by soft-rot Erwinias. Annu. Rev. Phytopathol. 25:405-430.

Lawton, K., Weymann, K., Friedrich, L., Vernooij, B., Uknes, S., and Ryals, J. 1995. Systemic acquired resistance in Arabidopsis requires salicylic acid but not ethylene. Mol. Plant-Microbe Interact. 8:863-870.

Malamy, J., Carr, J. P., Klessig, D. F., and Raskin, I. 1990. Salicylic acid: A likely endogenous signal in the resistance response of tobacco to viral infection. Science 250:1002-1004.

Martin, G. B., Brommonschenkel, S. H., Chunwongse, J., Frary, A., Ganal, M. W., Spivey, R., Wu, T., Earle, E. D., and Tanksley, S. D. 1993. Map-based cloning of a protein kinase gene conferring disease resistance in tomato. Science 262:1432-1436.

Métraux, J. P., Signer, H., Ryals, J., Ward, E., Wyss, B. M., Gaudin, J., Raschdorf, K., Schmid, E., Blum, W., and Inverardi, B. 1990. Increase in salicylic acid at the onset of systemic acquired resistance in cucumber. Science 250:1004-1006

Miller, J. H. 1972. Experiments in Molecular Genetics. Cold Spring Harbor Laboratory, Cold Spring Harbor, NY. p. 466.

Mur, L. A. J., Naylor, G., Warner, S. A. J., Sugars, J. M., White, R. F., and Draper, J. 1996. Salicylic acid potentiates defence gene expression in tissue exhibiting acquired resistance to pathogen attack. Plant J. 9:559-571.

Murashige, T., and Skoog, F. 1962. A revised medium for rapid growth and bioassays with tobacco tissue culture. Physiol. Plant. 15:473-497.

Norman, C., Vidal, S., and Palva, E. T. 1999. Oligogalacturonidemediated induction of a gene involved in jasmonic acid synthesis in response to the cell-wall-degrading enzymes of the plant pathogen Erwinia carotovora. Mol. Plant-Microbe Interact. 12:640-644.

Nürnberger, T., Nennstiel, D., Hahlbrock, K., and Scheel, D. 1995. Covalent cross-linking of the Phytophthora megasperma oligopeptide elicitor to its receptor in parsley membranes. Proc. Natl. Acad. Sci USA 92:2338-2342.

Nürnberger, T., Nennstiel, D., Jabs, T., Sacks, W. R., Hahlbrock, K., and Scheel, D. 1994. High affinity binding of a fungal oligopeptide elicitor to parsley plasma membranes triggers multiple defense responses. Cell 78:449-460.

Palva, T. K., Holmström, K.-O., Heino, P., and Palva, E. T. 1993. Induction of plant defense response by exoenzymes of Erwinia carotovora subsp. carotovora. Mol. Plant-Microbe Interact. 6:190-196.

Palva, T. K., Hurtig, M., Saindrenan, P., and Palva, E. T. 1994. Salicylic acid induced resistance to Erwinia carotovora subsp. carotovora in tobacco. Mol. Plant-Microbe Interact. 7:356-363.

Peña-Cortés, H., Albrecht, T., Prat, S., Weiler, E. W., and Willmitzer, L. 1993. Aspirin prevents wound-induced gene expression in tomato leaves by blocking jasmonic acid biosynthesis. Planta 191:123-128.

Penninckx, I. A. M. A., Eggermont, K., Terras, F. R. G., Thomma, B. P H. J., De Samblanx, G. W., Buchala, A., Métraux, J.-P., Manners, J. M., and Broekaert, W. F. 1996. Pathogen-induced systematic activation of a plant defensin gene in Arabidopsis follows a salicylic acidindependent pathway. Plant Cell 8:2309-2323.

Penninckx, I. A. M. A., Thomma, B. P. H. J., Buchala, A., Métraux, J.P., and Broekaert, W. F. 1998. Concomitant activation of jasmonate and ethylene response pathways is required for induction of a plant defensin gene in Arabidopsis. Plant Cell 10:2103-2113.

Pérombelon, M. C. M., and Kelman, A. 1980. Ecology of the soft rot Erwinias. Annu. Rev. Phytopathol. 18:361-387.

Pieterse, C. M. J., and van Loon, L. C. 1999. Salicylic acid-independent plant defense pathways. Trends Plant Sci. 4:52-58. 
Pieterse, C. M. J., van Wees, S. C. M., Hoffland, E., van Pelt, J. A., and van Loon, L. C. 1996. Systemic resistance in Arabidopsis induced by biocontrol bacteria is independent of salicylic acid accumulation and pathogenesis-related gene expression. Plant Cell 8:1225-1237.

Pieterse, C. M. J., van Wees, S. C. M., van Pelt, J. A., Knoester, M., Laan, R., Gerrits, H., Weisbeek, P. J., and van Loon, L. C. 1998. A novel signaling pathway controlling induced systemic resistance in Arabidopsis. Plant Cell 10:1571-1580.

Pirhonen, M., Heino, P., Helander, I., Harju, P., and Palva, E. T. 1988. Bacteriophage T4 resistant mutants of the plant pathogen Erwinia carotovora. Microb. Pathog. 4:359-367.

Pirhonen, M., Saarilahti, H., Karlsson, M.-B., and Palva, E. T. 1991. Identification of pathogenicity determinants of Erwinia carotovora subsp. carotovora by transposon mutagenesis. Mol. Plant-Microbe Interact. 4:276-283.

Potter, S., Uknes, S., Lawton, K., Winter, A. M., Chandler, D., DiMaio, J., Novitzky, R., Ward, E., and Ryals, J. 1993. Regulation of a heveinlike gene in Arabidopsis. Mol. Plant-Microbe Interact. 6:680-685.

Ryals, J. A., Neuenschwander, U. H., Willits, M. G., Molina, A., Steiner, H.-Y., and Hunt, M. D. 1996. Systemic acquired resistance. Plant Cell 8:1809-1819.

Samac, D. A., Hironaka, C. M., Yallaly, P. E., and Shah, D. M. 1990. Isolation and characterization of the genes encoding basic and acidic chitinase in Arabidopsis thaliana. Plant Physiol. 93:907-914

Sambrook, J., Fritsch, E. F., and Maniatis, T. A. 1989. Molecular Cloning: A Laboratory Manual. 2nd ed. Cold Spring Harbor Laboratory, Cold Spring Harbor, NY.

Shirasu, K., Nakajima, H., Rajasekhar, K., Dixon, R. A., and Lamb, C. 1997. Salicylic acid potentiates an agonist-dependent gain control that amplifies pathogen signals in the activation of defense mechanisms. Plant Cell 9:261-270.

Staskawicz, B. J., Ausubel, F. M., Baker, B. J., Ellis, J. G., and Jones, J. D. G. 1995. Molecular genetics of plant disease resistance. Science 268:661-667.

Uknes, S., Mauch-Mani, B., Moyer, M., Potter, S., Williams, S., Dincher, S., Chandler, D., Slusarenko, A., Ward, E., and Ryals, J. 1992. Acquired resistance in Arabidopsis. Plant Cell 4:645-656.

Verwoerd, T. C., Dekker, M. M., and Hockema, A. 1989. A small-scale procedure for the rapid isolation of plant RNAs. Nucleic Acids Res. $17: 2362$.

Vidal, S., Eriksson, A. R. B., Montesano, M., Denecke, J., and Palva, E. T. 1998. Cell wall-degrading enzymes from Erwinia carotovora cooperate in the salicylic acid-independent induction of a plant defense response. Mol. Plant-Microbe Interact. 1:23-32.

Vidal, S., Ponce de León, I., Denecke, J., and Palva, E. T. 1997. Salicylic acid and the plant pathogen Erwinia carotovora induce defense genes via antagonistic pathways. Plant J. 11:115-123.

Vijayan, P., Shockey, J., Levesque, C. A., Cook, R. J., and Browse, J. 1998. A role for jasmonate in pathogen defense of Arabidopsis. Proc. Natl. Acad. Sci. USA 95:7209-7214.

Ward, E. R., Uknes, S. J., Williams, S. C., Dincher, S. S., Wiederhold, D. L., Alexander, D. C., Ahl-Goy, P., Métraux, J.-P., and Ryals, J. A. 1991. Coordinate gene activity in response to agents that induce systemic acquired resistance. Plant Cell 3:1085-1094.

Xu, Y., Chang, P.-F. L., Liu, D., Narasimhan, M. L., Raghothama, K. G. Hasegawa, P. M., and Bressan, R. A. 1994. Plant defense genes are synergistically induced by ethylene and methyl jasmonate. Plant Cell 6:1077-1085 